\title{
Flora of Singapore precursors, 29: A new name for Ficus dubia Wall. ex King (Moraceae)
}

\author{
H.J. Beentje \\ Royal Botanic Gardens, Kew, Richmond, \\ Surrey, TW9 3AE, U.K. \\ h.beentje@kew.org
}

ABSTRACT. The new name Ficus lindsayana Beentje is proposed for the later homonym Ficus dubia Wall. ex King (Moraceae).

Keywords. Ficus dubia Göpp., Ficus lindsayana, fossil, homonym, replacement name

\section{Introduction}

Ficus dubia Wall. ex King (Moraceae) is a large scrambling fig of Peninsular Malaysia, Singapore, Sumatra and northern Borneo. This taxon name was first published by King (1888) based on a Wallich specimen from Penang, a Forbes specimen from Sumatra and a King specimen from Malacca. As the taxon is not uncommon in lowland forest the name has figured in many regional publications including the authoritative Flora Malesiana (Berg \& Corner, 2005). Why this taxon was named dubia (from the Latin for doubtful) was never explained - in fact, King states it is a very distinct species.

It has recently come to my attention that this name is a later homonym of Ficus dubia Göpp. (Göppert, 1854), based on an incompletely preserved fossil, now at the Nederlands Centrum voor Biodiversiteit (NCB Naturalis) (Van Konijnenburgvan Cittert et al., 2004). Despite the fragmentary nature of both the holotype and the description, this name was validly published.

A replacement name is therefore necessary for Ficus dubia Wall. ex King.

\section{Replacement name}

Ficus lindsayana Beentje, nom. nov. - Ficus dubia Wall. ex King, Ann. Roy. Bot. Gard. (Calcutta) 1: 46, tt. 56, 83k (1887), nom. illeg. non Göpp. (1854); Ridley, Fl. Malay Penins. 3: 333 (1924); Kochummen in Ng (ed.), Tree Fl. Malaya 3: 146 (1978); Corner, Wayside Trees Malaya, ed. 3, 2: 541 (1988); Keng, Concise Fl. Singapore, vol. 1, Gymn. Dicot. 70 (1990); Turner et al., J. Singapore Natl. Acad. Sci. 18 \& 19: 75 (1990); Turner, Gard. Bull. Singapore 45: 142 (1993); Lee et al., Gard. Bull. Singapore 55: 300 (2003); Berg \& Corner, F1. Males., ser. 1, 17(2): 653 (2005); Tan et al. in Davison et al. (eds), Singapore Red Data Book, ed. 2: 230 (2008); Chong et al., 
Checkl. Vasc. Pl. Fl. Singapore 41, 151, 205 (2009); Turner \& Chua, Checkl. Vasc. P1. Sp. Bukit Timah Nat. Reserve 49 (2011); Ho et al., Gard. Bull. Singapore 71 (Suppl. 1): 95 (2019). - TYPE: [Peninsular Malaysia], Malacca, 1879, King s.n. (lectotype K, designated here).

Eponymy. The specific epithet honours Dr Stuart Lindsay, who brought this case to my attention.

\section{References}

Berg, C.C. \& Corner, E.J.H. (2005). Moraceae - Ficus. Flora Malesiana, ser. 1, Seed Plants, vol. 17, pt. 2. Leiden: Nationaal Herbarium Nederland.

Göppert, H.R. (1854). Die Tertiärflora auf der Insel Java, nach den Entdeckungen des Herrn Fr. Junghuhn. 's Gravenhage: Mieling.

Van Konijnenburg-van Cittert, J.H.A., Van Waveren, I.M. \& Jonkers, J.B. (2004). Catalogue of the Mesozoic and Cenozoic holotypes in the collection of plant fossils in the Nationaal Natuurhistorisch Museum, Leiden. NNM Techn. Bull. 7: 1-27. 